\title{
Hubungan Dosis Kumulatif Doksorubisin Terhadap Fungsi Sistolik Ventrikel Kiri pada Penyintas Leukemia Limfoblastik Akut
}

Patricia Yulita Gunawan, ${ }^{*}$ Erling David Kaunang, ${ }^{* *}$ Max Frans Joseph Mantik, ${ }^{* *}$ Stefanus Gunawan ${ }^{* *}$

"Departemen Ilmu Kesehatan Anak Fakultas Kedokteran, Universitas Pelita Harapan / RS Siloam, Karawaci, " Departemen Ilmu Kesehatan Anak Fakultas Kedokteran, Universitas Sam Ratulangi / RS Prof. dr. R.D. Kandou, Manado

Latar belakang. Seiring meningkatnya angka harapan hidup anak dengan leukemia limfoblastik akut (LLA), kardiotoksisitas akibat kemoterapi seperti antrasiklin menjadi semakin penting. Evaluasi berkala fungsi sistolik ventrikel kiri melalui fraksi ejeksi (FE) dan fraksi pemendekan (FP) direkomendasikan untuk pemantauan efek samping kardiotoksisitas antrasiklin.

Tujuan. Penelitian ini bertujuan untuk melihat hubungan antara dosis kumulatif doksorubisin dengan fungsi sistolik ventrikel kiri pada penyintas LLA anak.

Metode. Penelitian ini menggunakan metode kohort retrospektif dengan menilai perubahan FE dan FP menggunakan ekokardiografi pada penyintas LLA pada bulan Juli-September 2016 di bagian Ilmu Kesehatan Anak, RSU Prof. dr. R. D. Kandou, Manado. Pengambilan sampel dilakukan dengan cara total sampling. Analisis statistik dilakukan dengan menggunakan korelasi Pearson.

Hasil. Terdapat total 18 penyintas LLA yang diteliti, termasuk 12 risiko standar dan 6 risiko tinggi. Fungsi sistolik ventrikel kiri semua penyintas masih dalam batas normal (FE 74,20 $\pm 11,37 \%$, FP 42,61 $\pm 9,98 \%$ ). Ditemukan adanya hubungan negatif sedang yang bermakna antara dosis kumulatif doksorubisin dan fungsi sistolik ventrikel kiri [FE $(r=-0,532, p=0,012)$ dan $F P(r=-0,518$, $p=0,014)]$. Kesimpulan. Terdapat hubungan negatif antara dosis kumulatif doksorubisin dan fungsi sistolik ventrikel kiri pada penyintas LLA anak. Panduan lokal diperlukan untuk evaluasi ekokardiografi secara berkala pada penyintas LLA anak di Indonesia. Sari Pediatri $2018 ; 20(3): 165-70$

Kata kunci: leukemia limfoblastik akut, doksorubisin, fungsi sistolik ventrikel kiri, anak

\section{Effect of Doxorubicin Cumulative Dose to Left Ventricle Systolic Function in Pediatric Acute Lymphoblastic Leukemia Survivors}

Patricia Yulita Gunawan, ${ }^{*}$ Erling David Kaunang, ${ }^{* *}$ Max Frans Joseph Mantik, ${ }^{* *}$ Stefanus Gunawan ${ }^{* *}$

Background. As pediatric acute lymphoblastic leukemia (ALL) survival increases, cardiotoxicity associated with chemotherapeutic regimens such as anthracyclines become a more significant issue. Assessment of the left ventricle (LV) systolic function with ejection fraction (EF) and fractional shortening (FS) was recommended for monitoring of anthracycline therapy.

Objective. This study aims to assess the correlation between doxorubicin cumulative dose and LV systolic function in pediatric ALL survivors.

Methods. We performed a retrospective cohort study by evaluating changes of EF and FS using echocardiography from July to September 2016 in Pediatric division, Prof. dr. R. D. Kandou hospital, Manado. Sampling was done by total sampling. Statistical analysis assessment used Pearson correlation.

Results. A total of 18 ALL survivors, including 12 standard risk (SR) and 6 high risk (HR), were included. The LV systolic functions of all survivors were still in normal limit (EF 74.20 $\pm 11.37 \%$, FS $42.61 \pm 9.98 \%$ ). We found a significant moderate negative correlation between doxorubicin cumulative dose and LV systolic function [both EF $(r=-0.532, p=0.012)$ and FS $(r=-0.518, p=0.014)$ ] Conclusion. Our study found a negative correlation between doxorubicin cumulative dose and LV systolic function in pediatric ALL survivors. A local guideline is needed for regular echocardiographic evaluation of Indonesian pediatric ALL survivors. Sari Pediatri 2018;20(3):165-70

Keywords: acute lymphoblastic leukemia, doxorubicin, left ventricle systolic function, pediatric

Alamat korespondensi: Patricia Yulita Gunawan. Bagian Ilmu Kesehatan Anak FK. Universitas Pelita Harapan/ RSU Siloam Karawaci. Jl. Boulevard Jendral Sudirman, Lippo Karawaci, Tangerang. E-mail: patricia.gunawan@uph.edu 
Patricia Yulita Gunawan dkk: Hubungan dosis kumulatif doksorubisin terhadap fungsi sistolik ventrikel kiri pada penyintas LLA

$\mathrm{L}$

eukemia adalah keganasan tersering pada anak. ${ }^{1}$ Angka harapan hidup pada anak dengan leukemia limfoblastik akut (LLA) meningkat dalam empat dekade terakhir. Angka harapan hidup lima tahun mencapai 90\% di St. Jude Children's Research Hospital. ${ }^{2}$ Di negara berkembang angka harapan hidup jauh di bawah negara maju, yaitu biasanya $<35 \%{ }^{3}$ Di Indonesia, angka harapan hidup LLA masih kurang memuaskan, dengan event-free survival bervariasi antara 20\%-60\%.,

Peningkatan jumlah penyintas LLA anak di Indonesia menyebabkan identifikasi efek samping jangka panjang terapi menjadi semakin penting. ${ }^{6}$ Salah satu efek samping jangka panjang adalah kardiotoksisitas yang diinduksi antrasiklin. Antrasiklin seperti daunorubisin, epirubisin dan doksorubisin telah digunakan selama lebih dari 30 tahun, dan hampir $60 \%$ anak dengan keganasan mendapat pengobatan dengan obat tersebut. ${ }^{7}$

Pada penelitian potong lintang di RS dr. Soetomo Surabaya, dari 19 anak penderita LLA paska terapi daunorubisin didapatkan 12 anak mengalami gangguan fungsi diastolik ventrikel kiri dengan pola penurunan relaksasi. ${ }^{8}$ Penelitian lain yang mengidentifikasi efek kardiotoksik obat golongan antrasiklin yang digunakan dalam terapi keganasan pada anak di Pakistan menemukan bahwa 14\% anak mengalami disfungsi jantung dalam satu bulan paska terapi antrasiklin. ${ }^{9}$

Efek kardiotoksik antrasiklin secara klinis memberikan gambaran klinis gagal jantung, sementara secara subklinis hanya memberikan gambaran kelainan jantung melalui berbagai metode diagnostik tapi secara klinis asimptomatik. ${ }^{7}$ Efek kardiotoksik antrasiklin dapat bersifat akut (terjadi pada saat atau segera sesudah administrasi), yaitu dapat berupa perubahan pada gambaran elektrokardiografi (EKG) termasuk pemanjangan interval QT dan aritmia; subakut (dalam beberapa hari atau minggu setelah administrasi), termasuk miokarditis toksik atau perikarditis, dan dapat bersifat kronik (dalam beberapa minggu atau bulan setelah administrasi) yang bermanifestasi sebagai kardiomiopati. ${ }^{10}$

Penilaian fungsi sistolik ventrikel kiri dengan fraksi ejeksi (FE) dan fraksi pemendekan (FP) direkomendasikan dalam pedoman praktik klinis untuk pemantauan efek samping kardiotoksisitas antrasiklin. ${ }^{11}$ Di negara berkembang, terdapat berbagai pedoman mengenai pemantauan jangka panjang pada penyintas anak dengan keganasan. ${ }^{12,13}$ Di Indonesia sendiri belum ada program pemantauan jangka panjang pada penyintas LLA anak.

Penelitian-penelitian sebelumnya menunjukkan bahwa kardiotoksisitas doksorubisin bergantung pada dosis kumulatif; akan tetapi, sangat sedikit penelitian yang menggunakan dosis kumulatif doksorubisin kurang dari $150 \mathrm{mg} / \mathrm{m}^{2} .^{14,15}$ Pada protokol terapi LLA Indonesia 2006, pasien anak diterapi dengan dosis kumulatif doksorubisin yang rendah. Tujuan penelitian ini adalah untuk menganalisis hubungan antara dosis kumulatif doksorubisin dan fungsi sistolik ventrikel kiri pada penyintas LLA anak yg diterapi dengan protokol LLA Indonesia 2006.

\section{Metode}

Kami melakukan penelitian kohort retrospektif selama bulan Juli sampai dengan bulan September 2016 di ruang onkologi anak Estella di RS Prof. dr. R. D. Kandou, Manado. Semua penyintas LLA yang sebelumnya pernah menyelesaikan terapi di Estella dihubungi. Penyintas LLA yang telah menyelesaikan protokol terapi LLA Indonesia 2006 (Gambar 1 \& 2) dan setuju menanda-tangani informed consent dimasukkan dalam penelitian. Penyintas dengan penyakit jantung kongenital dan didapat yang telah terdiagnosis di awal terapi, dengan sindrom Down, dalam terapi dengan $\beta$-blocker dan/atau angiotensin converting enzyme inhibitor (ACE-I), dengan systemic inflammatory response syndrome (SIRS) dan dengan end stage renal disease (ESRD) dieksklusi.

Sampel diambil dengan cara total sampling. Sampel dibagi menjadi dua kelompok: kelompok LLA risiko standar yang menerima dosis kumulatif doksorubisin sebesar $80 \mathrm{mg} / \mathrm{m}^{2}$ dan kelompok LLA risiko tinggi yang menerima dosis kumulatif doksorubisin sebesar $120 \mathrm{mg} / \mathrm{m}^{2}$ (Gambar 1 dan 2). Kelompok LLA risiko tinggi meliputi mereka dengan usia kurang dari satu tahun atau lebih dari 10 tahun, jumlah leukosit awal $>50.000 / \mathrm{mm}^{3}$, adanya massa mediastinum, infiltrasi sistem saraf pusat (SSP), LLA T-lineage atau ditemukan sel blas $>1.000 / \mathrm{mm}^{3}$ setelah satu minggu terapi dengan prednison dan satu kali pemberian metotreksat intratekal. Pada penelitian ini, kami tidak menggunakan agen profilaktik (seperti deksrazoksan) dan doksorubisin yang digunakan adalah doksorubisin $\mathrm{HCl}$ (non-liposomal). 
Pemeriksaan ekokardiografi dilakukan pada semua sampel penelitian yang memenuhi kriteria inklusi. Rentang waktu antara terapi doksorubisin terakhir dan ekokardiografi bervariasi antar sampel. Fungsi sistolik ventrikel kiri ditentukan dengan pengukuran FE dan FP melalui ekokardiografi; gangguan fungsi sistolik ventrikel kiri didefinisikan dengan $\mathrm{FE}<50 \%$ dan FP $<28 \%$. Ekokardiogram dilakukan di RS Prof. dr. R. D. Kandou oleh seorang dokter spesialis anak konsultan kardiologi. Penelitian ini dilaksanakan di bawah persetujuan Komite Etik Kesehatan dari RS Prof. dr. R. D. Kandou, Manado.

Hasil FE dan FP yang didapat dari ekokardiografi dibandingkan dengan hasil FE dan FP awal sebelum dimulai terapi doksorubisin. Analisis statistik dilakukan dengan korelasi Pearson menggunakan SPSS versi 22. Hasil dikatakan signifikan bila $\mathrm{p}<0,05$.

\section{Hasil}

Terdapat total 55 penyintas LLA, 4 di antaranya tidak bisa dihubungi. Empat puluh satu setuju untuk berpartisipasi. Dua subjek dieksklusi karena tidak diterapi dengan protokol terapi LLA Indonesia 2006. Dua puluh satu subjek dieksklusi karena data hasil ekokardiografi di awal terapi tidak ditemukan. Delapan belas subjek yang tersisa terdiri dari 12 risiko standar dan 6 risiko tinggi. Usia subjek saat diagnosis adalah antara 1 tahun 11 bulan dan 12 tahun 11 bulan dengan rerata usia 5 tahun 6 bulan. Rasio lelaki:perempuan adalah 1,25:1. Rerata FE penyintas LLA risiko standar adalah 79,03 (SD $\pm 10,64) \%$ dan risiko tinggi adalah $64,55$ (SD $\pm 4,78) \%$. Rerata FP penyintas LLA risiko standar adalah 46,67 (SD $\pm 9,73) \%$ dan risiko tinggi adalah 34,48 (SD $\pm 3,38) \%$. Rerata selisih FE sesudah dan sebelum terapi pada kelompok risiko standar adalah 11,19 (SD $\pm 15,67) \%$ dan pada kelompok risiko tinggi adalah $-7,45$ (SD $\pm 12,87) \%$. Rerata selisih FP sesudah dan sebelum terapi pada kelompok risiko standar adalah 9,25 (SD $\pm 13,85) \%$ dan pada kelompok risiko tinggi adalah $-6,68(\mathrm{SD} \pm 11,46) \%$. Rentang waktu minimal antara terapi doksorubisin terakhir dan ekokardiografi adalah 0 bulan dan maksimum 4 tahun 11 bulan (Tabel 1).

Penelitian ini mendapatkan adanya korelasi negatif sedang yang signifikan antara dosis kumulatif doksorubisin dan fungsi sistolik ventrikel kiri [FE ( $\mathrm{r}=-$ 0,532, $\mathrm{p}=0,012)$ dan FP $(\mathrm{r}=-0,518, \mathrm{p}=0,014)]$.

\section{Pembahasan}

Kami menemukan angka penyintas LLA risiko tinggi lebih rendah dibanding risiko standar, mungkin disebabkan oleh angka kematian pada penyintas LLA risiko tinggi lebih tinggi, seperti ditunjukkan pada penelitian-penelitian sebelumnya di Indonesia. ${ }^{3,16}$

Hasil fungsi sistolik ventrikel kiri yang didapat dari penelitian ini lebih tinggi dibanding hasil-hasil

Tabel 1. Karakteristik sampel (N=39)

\begin{tabular}{|c|c|c|c|c|c|}
\hline \multirow{2}{*}{$\frac{\text { Karakteristik }}{\text { Jenis kelamin }}$} & & \multirow{2}{*}{$\begin{array}{c}\text { Populasi } \\
10\end{array}$} & \multirow{2}{*}{$\frac{\text { LLA risiko standar }}{5}$} & \multirow{2}{*}{$\frac{\text { LLA risiko tinggi }}{5}$} & \multirow[t]{2}{*}{$\mathrm{p}$} \\
\hline & Lelaki & & & & \\
\hline & Perempuan & 8 & 7 & 1 & \\
\hline \multicolumn{2}{|c|}{ Usia, bulan, rerata $(\mathrm{SD})$} & $86,94(42,67)$ & $68,92(18,56)$ & $123,00(55,61)$ & 0,06 \\
\hline \multicolumn{2}{|c|}{ Usia saat dimulai terapi doksorubisin, bulan, rerata (SD) } & $66,06(33,59)$ & $53,75(17,50)$ & $90,67(45,52)$ & 0,11 \\
\hline \multicolumn{2}{|c|}{$\begin{array}{l}\text { Fraksi ejeksi sebelum dimulai terapi doksorubisin, \%, rerata } \\
\text { (SD) }\end{array}$} & $69,22(8,82)$ & $67,83(8,35)$ & $72,00(9,84)$ & 0,36 \\
\hline \multicolumn{2}{|c|}{$\begin{array}{l}\text { Fraksi pemendekan sebelum dimulai terapi doksorubisin, } \\
\% \text {, rerata }(\mathrm{SD})\end{array}$} & $38,67(8,05)$ & $37,42(7,13)$ & $41,17(9,87)$ & 0,37 \\
\hline \multicolumn{2}{|c|}{$\begin{array}{l}\text { Interval waktu antara terapi doksorubisin terakhir } \\
\text { dengan saat evaluasi, bulan, median (min, maks) }\end{array}$} & $16,50(0,59)$ & $12,50(0,33)$ & $18,50(2,59)$ & 0,10 \\
\hline \multicolumn{2}{|c|}{$\begin{array}{l}\text { Fraksi ejeksi sesudah diberikan terapi doksorubisin, \%, } \\
\text { rerata (SD) }\end{array}$} & $74,20(11,37)$ & $79,03(10,64)$ & $64,55(4,78)$ & 0,01 \\
\hline \multicolumn{2}{|c|}{$\begin{array}{l}\text { Fraksi pemendekan sesudah diberikan terapi doksorubisin, } \\
\% \text {, rerata }(\mathrm{SD})\end{array}$} & $42,61(9,98)$ & $46,67(9,73)$ & $34,48(3,38)$ & 0,00 \\
\hline
\end{tabular}




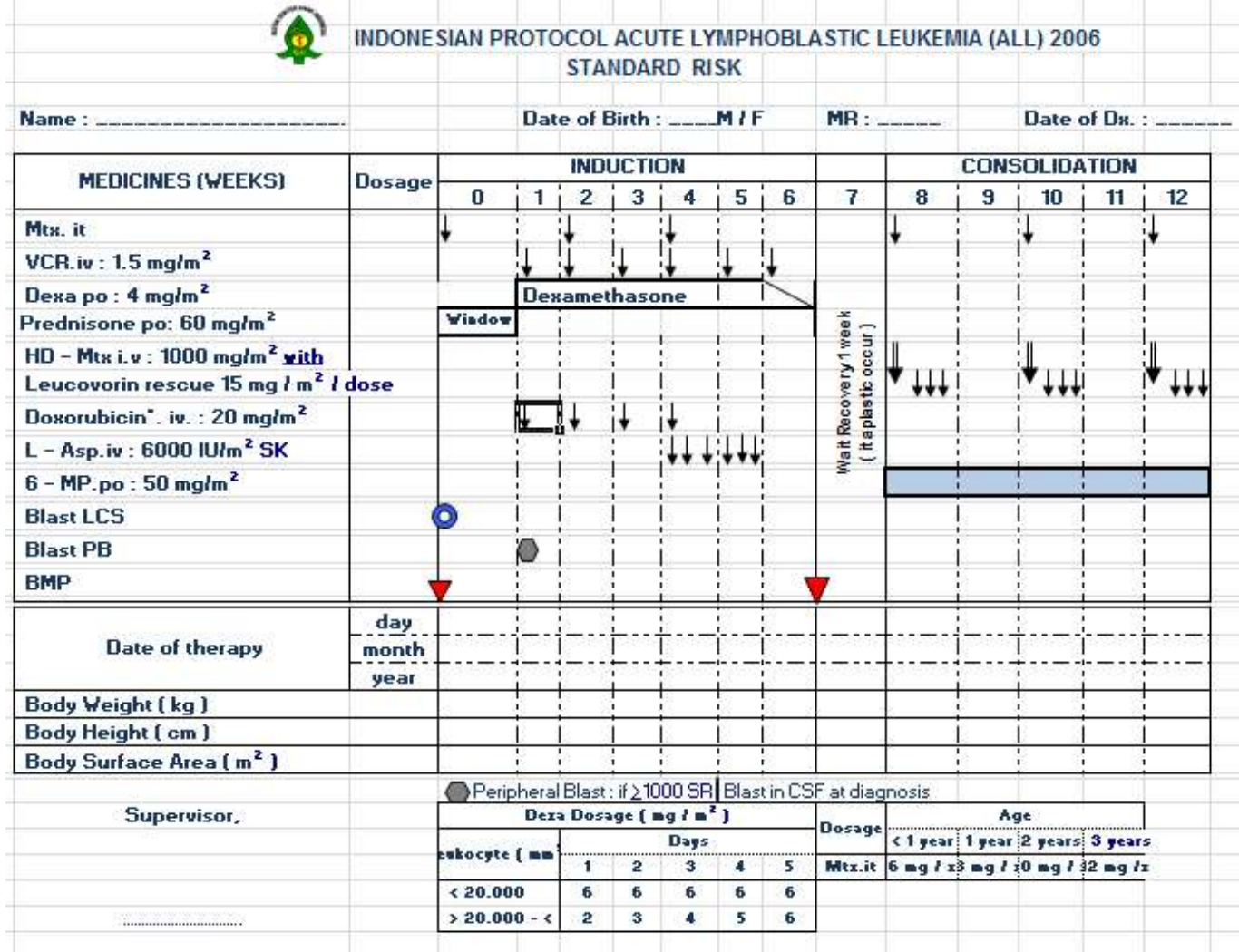

Gambar 1. Protokol terapi LLA risiko standar Indonesia 2006

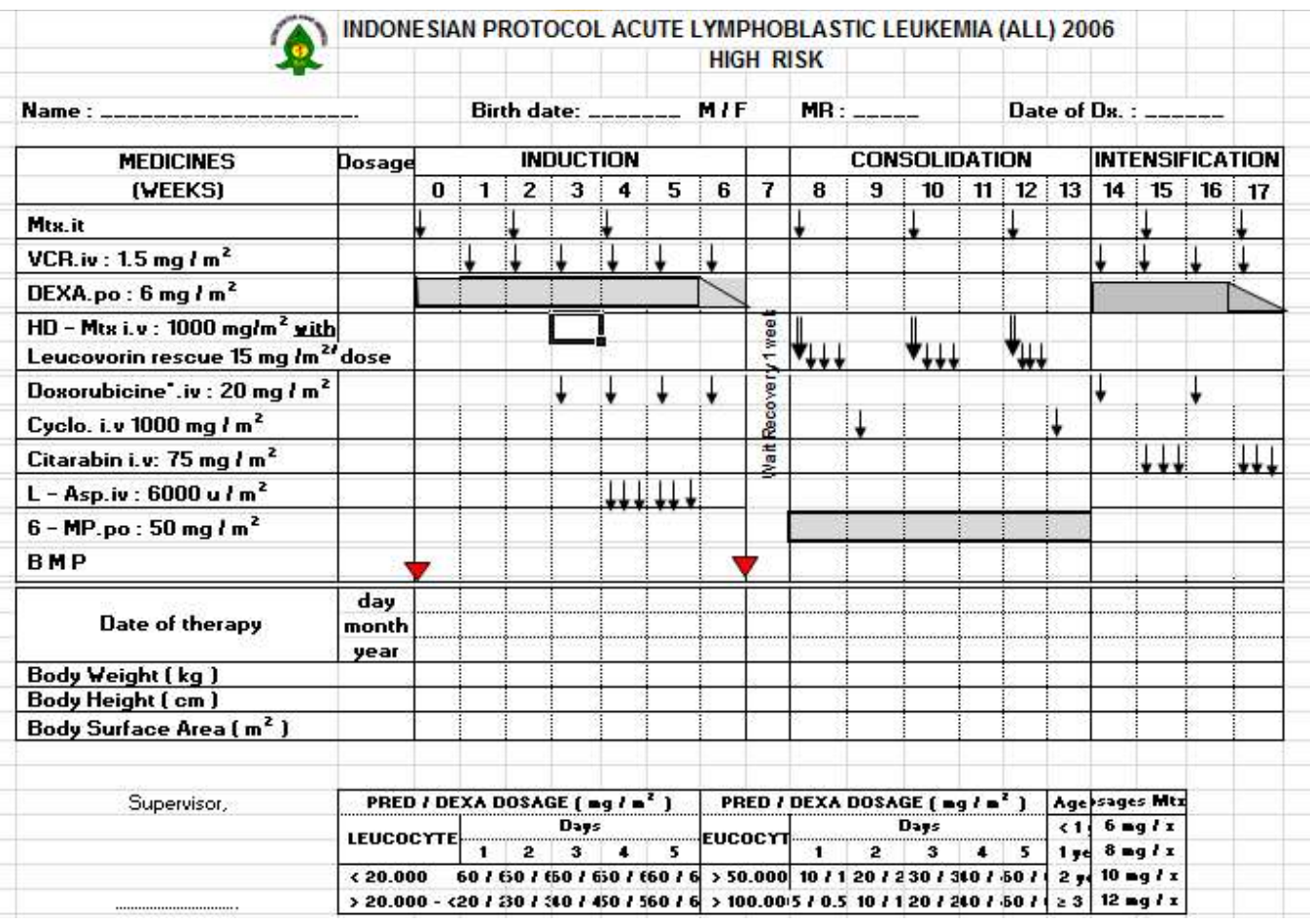

Gambar 2. Protokol terapi LLA risiko tinggi Indonesia 2006 
penelitian sebelumnya yang meneliti subjek yang mendapatkan terapi antrasiklin dengan rerata dosis kumulatif yang lebih tinggi dan interval waktu yang lebih panjang antara terapi doksorubisin terakhir dengan dilakukannya penilaian fungsi jantung. Hasil penelitian pada penyintas keganasan di St Jude Children's Research Hospital (Memphis) dengan jarak terapi antrasiklin terakhir dan dilakukannya ekokardiografi 3-18 tahun mendapatkan rerata FP $33,3(\mathrm{SD} \pm 5,7) \%$ pada kelompok yang mendapat terapi antrasiklin dengan median dosis 201,8 (25-510) $\mathrm{mg} / \mathrm{m}^{2}{ }^{17}$ Penelitian lain oleh Vandecruys $\mathrm{dkk}^{18}$ yang dilakukan pada 77 penyintas LLA di Departemen Hemato-onkologi Pediatri Ghent University Hospital (Belgia) yang menerima dosis kumulatif antrasiklin sebesar $180-240 \mathrm{mg} / \mathrm{m}^{2}$ dengan rerata jarak terapi antrasiklin terakhir dan dilakukannya ekokardiografi 13,6 tahun mendapatkan rerata FE 61,3 (54,6-70,5)\% dan FP $34,0(28,6-39,4) \%$ pada laki-laki serta FE $66,6(58,6-71,6) \%$ dan FP 36,9 $(30,4-40,8) \%$ pada perempuan.

Hubungan antara interval pasca terapi dan kardiotoksisitas oleh antrasiklin ditunjukkan oleh suatu studi kohort prospektif di Pakistan yang menganalisis gangguan jantung melalui tiga pemeriksaan ekokardiografi berturut-turut (di awal, sebulan setelahnya dan satu tahun post kemoterapi) pada anak dengan keganasan yang mendapatkan terapi antrasiklin. Penelitian ini menemukan bahwa 14\% pasien mengalami gangguan jantung berupa penurunan myocardial performance index melalui pemeriksaan ekokardiografi dalam waktu sebulan setelah selesainya terapi, yang meningkat menjadi 25\% dalam satu tahun setelah selesainya terapi. ${ }^{?}$

Hasil korelasi negatif yang bermakna antara dosis kumulatif doksorubisin dan fungsi sistolik ventrikel kiri yang ditemukan dari penelitian kami sejalan dengan hasil penelitian Lipshultz $\mathrm{dkk},{ }^{15}$ yang melaporkan adanya hubungan yang bermakna antara penurunan fungsi jantung (meliputi kontraktilitas ventrikel kiri (stress-velocity index), dimensi ventrikel kiri di akhir fase diastol, massa ventrikel kiri, FP ventrikel kiri, afterload ventrikel kiri dan rasio ketebalan dinding terhadap dimensi ventrikel kiri) dengan dosis kumulatif doksorubisin yang lebih besar. Pada penelitian tersebut besaran korelasi tidak dinilai, melainkan digambarkan dalam bentuk kurva $z$-score. Hasil yang serupa ditunjukkan oleh Smibert $\mathrm{dkk}^{19}$ yang menyimpulkan bahwa dosis antrasiklin yang lebih tinggi berhubungan dengan perbedaan yang lebih tinggi pada puncak FP antara subjek dan kontrol.

Nilai fungsi sistolik ventrikel kiri pada penelitian kami didapatkan masih dalam batas normal, berbeda dengan penelitian sebelumnya yang menunjukkan adanya gangguan fungsi sistolik ventrikel kiri. ${ }^{16,20,21}$ Perbedaan hasil ini mungkin disebabkan dosis kumulatif doksorubisin lebih tinggi dan interval pasca terapi yang lebih lama pada penelitian sebelumnya. Nilai normal fungsi sistolik ventrikel kiri pada penelitian ini harus diinterpretasi dengan hati-hati.

Dosis kumulatif doksorubisin penelitian kami lebih rendah dibandingkan penelitian lain sebelumnya, tetapi telah terlihat perbedaan fungsi sistolik ventrikel kiri antara kedua kelompok terapi yang mendapatkan dosis kumulatif doksorubisin yang berbeda. Hasil tersebut serupa dengan hasil kohort pada anak yang diterapi dengan protokol LLA Dana Farber. Penelitian tersebut melaporkan bahwa bahkan pasien yang mendapatkan dosis kumulatif doksorubisin serendah $45 \mathrm{mg} / \mathrm{m}^{2}$ mengalami gangguan fungsi jantung setelah pemantauan selama 11,8 tahun; menunjukkan bahwa tidak ada dosis aman untuk doksorubisin yang bebas dari efek kardiotoksik. ${ }^{16}$

European Society for Medical Oncology (ESMO) merekomendasikan pemantauan rutin fungsi sistolik ventrikel kiri, bahkan pada pasien yang asimptomatis, pada waktu-waktu sebagai berikut: setelah pemberian setengah dari dosis antrasiklin yang direncanakan, atau setelah pemberian dosis kumulatif doksorubisin $300 \mathrm{mg} / \mathrm{m}^{2}$ atau setelah pemberian dosis kumulatif doksorubisin $240 \mathrm{mg} / \mathrm{m}^{2}$ pada pasien berusia $<15$ tahun atau $>60$ tahun; sebelum setiap pemberian antrasiklin berikutnya; setelah 3,6 dan 12 bulan sejak selesainya terapi dengan antrasiklin. ${ }^{22}$

Penelitian kami memiliki keterbatasan, berhubungan dengan jumlah sampel yang sedikit akibat tidak ditemukannya sebagian data ekokardiografi awal dan durasi antara penggunaan obat terakhir dengan pemeriksaan fungsi jantung yang bervariasi, yang mungkin tidak dapat mendeteksi perbedaan yang kecil. Ekokardiografi juga hanya dilakukan oleh satu orang dokter spesialis anak konsultan kardiologi, yang disebabkan belum tersedianya dokter spesialis anak konsultan kardiologi lain di kota Manado. Di lain pihak, penelitian kami memiliki kelebihan dalam memperluas pengetahuan mengenai efek kardiotoksik dari dosis antrasiklin yang belum pernah diteliti sebelumnya. 
Sebagai kesimpulan, pada penyintas LLA anak, ditemukan korelasi sedang yang bermakna antara dosis kumulatif doksorubisin dan fungsi sistolik ventrikel kiri. Suatu pedoman lokal diperlukan untuk jadwal pemantauan rutin ekokardiografi pada penyintas LLA anak.

\section{Daftar pustaka}

1. World Health Organization. 2009. Incidence of childhood leukaemia. Diakses pada April 1, 2015. Didapat dari: www. euro.who.int/ENHIS.

2. Mariotto AB, Rowland JH, Yabroff KR, Scoppa S, Hachey M, Ries L, dkk. Long-term survivors of childhood cancers in the United States. Cancer Epidemiol Biomarkers Prev 2009; 18:1033-40.

3. Metzger ML, Howard SC, Fu LC, Peña A, Stefan R, Hancock ML, dkk. Outcome of childhood acute lymphoblastic leukaemia in resource-poor countries. Lancet 2003;362:706-8.

4. Mostert S, Sitaresmi MN, Gundy CM, Sutaryo, Veerman AJP. Influence of socioeconomic status on childhood acute lymphoblastic leukemia treatment in Indonesia. Pediatrics 2006;118:e1600-6.

5. Djajadiman G, Endang W. Treatment of childhood acute lymphoblastic leukemia in Jakarta: result of modified Indonesian National Protocol 94. Paediatr Indones 2006;46:179-84.

6. Robison LL. Late effects of acute lymphoblastic leukemia therapy in patients diagnosed at 0-20 years of age. Hematology Am Soc Hematol Educ Program 2011;2011:238-42.

7. Kremer LCM, Caron HN. Anthracycline cardiotoxicity in children. N Engl J Med 2004;351:120-1.

8. Rahman MA. Fungsi sistolik dan diastolik ventrikel kiri pada anak dengan leukemia limfoblastik akut pasca terapi daunorubicin. Sari Pediatri 2005;7:160-8.

9. Shaikh AS, Saleem AF, Mohsin SS, Alam MM, Ahmed MA. Anthracycline-induced cardiotoxicity: prospective cohort study from Pakistan. BMJ Open 2013.doi: 10.1136/ bmjopen-2013-003663.

10. Sawyer DB, Peng X, Chen B, Pentassuglia L, Lim CC. Mechanisms of anthracycline cardiac injury: can we identify strategies for cardioprotection? Prog Cardiovasc Dis 2010;53:105-13.

11. Al-Biltagi M, Tolba OARE, El-Shanshory MR, El-Shitany NAE, El-Hawary EE. Strain echocardiography in early detection of doxorubicin-induced left ventricular dysfunction in children with acute lymphoblastic leukemia. ISRN Pediatr 2012;2012:870549.

12. Children's Oncology Group. Long-term follow-up guidelines for survivors of childhood, adolescent, and young adult cancers. Diakses pada 29 November 2016. Didapat dari: $w w w$. survivorshipguidelines.org.

13. Scottish Intercollegiate Guidelines Network. Long term follow up of survivors of childhood cancer-A national clinical guideline. March 2013. Diakses pada 29 November 2016. Didapat dari: www.sign.ac.uk.

14. Swain SM, Whaley FS, Ewer MS. Congestive heart failure in patients treated with doxorubicin. Cancer 2003;97:2869-79.

15. Lipshultz SE, Lipsitz SR, Sallan SE, Dalton VM, Mone SM, Gelber RD, dkk. Chronic progressive cardiac dysfunction years after doxorubicin therapy for childhood acute lymphoblastic leukemia. J Clin Oncol 2005;23:2629-36.

16. Widiaskara IM, Permono B, Ugrasena IDG, Ratwita M. Luaran pengobatan fase induksi pasien leukemia limfoblastik akut pada anak di Rumah Sakit Umum dr. Soetomo Surabaya. Sari Pediatri 2010;12:128-34.

17. Hudson MM, Rai SN, Nunez C, Merchant TE, Marina NM, Zalamea N, dkk. Noninvasive evaluation of late anthracycline cardiac toxicity in childhood cancer survivors. J Clin Oncol 2007;25:3635-43.

18. Vandecruys E, Mondelaers V, Wolf DD, Benoit Y, Suys B. Late cardiotoxicity after low dose of anthracycline therapy for acute lymphoblastic leukemia in childhood. J Cancer Surviv 2012;6:95-101.

19. Smibert E, Carlin JB, Vidmar S, Wilkinson LC, Newton M, Weintraub RG. Exercise echocardiography reflects cumulative anthracycline exposure during childhood. Pediatr Blood Cancer 2004; 42:556-62.

20. Trachtenberg BH, Landy DC, Franco VI, Henkel JM, Pearson EJ, Miller TL, dkk. Anthracycline-associated cardiotoxicity in survivors of childhood cancer. Pediatr Cardiol 2011;32:34253.

21. Agarwala S, Kumar R, Bhatnagar V, Bajpai M, Gupta DK, Mitra DK. High incidence of adriamycin cardiotoxicity in children even at low cumulative doses: role of radionuclide cardiac angiography. J Pediatr 2000;35:1786-9.

22. Bovelli D, Plataniotis G, Roila F. Cardiotoxicity of chemoterapeutic agents and radiotherapy-related heart disease: ESMO Clinical Practice Guidelines. Ann. Oncol 2010;21:v277-82. 